\title{
A PARTICIPATORY OUTLINE OF TRIBAL WOMEN OF ANDHRA PRADESH IN FARMING ACTIVITIES
}

\author{
Y. UMA JYOTHI ${ }^{1}$, N. SUNITHA ${ }^{2} \&$ NISHI SETHI ${ }^{3}$ \\ ${ }^{I}$ P.G. Student, Department of Home Science Extension Education, CCS Haryana Agricultural University, Hissar, India \\ ${ }^{2}$ Research Scholar, Department of Home Science Extension and Communication Management, PJTSAU, Hyderabad, India \\ ${ }^{3}$ Professor Department of Home Science Extension Education, College of Home Science, CCS HAU, Hissar, India
}

\begin{abstract}
The present study was made known from the data collected from 100 tribal women, who were involved in farming. The study was undertaken in randomly selected two villages Rajam (plain) and Palakonda (hilly) of Srikakulam district. District Srikakulam was randomly selected out of all the five districts of Andhra Pradesh, having tribal population to find out the participation of tribal women in different farming activities. The data were collected through a structured interview schedule, personally from tribal (SAVARA) woman who was involved in Farming. Appropriate statistical analysis was used, to explore the results. The results of the study revealed that, $63 \%$ of the total respondents were participating in farming activities. Maximum involvement of women was seen in activities like cleaning, storage structure with a weighted mean score (1.95) ranking first, followed by manure preparation (1.91) ranking second and seed treatment (1.75) among the farming activities. Less involvement of tribal women was studied in hard activities like ploughing transportation of produce, levelling of land ethic, as they require high energy and are strenuous.

KEYWORDS: Participation \& Tribal Women in Agriculture
\end{abstract}

Received: Aug 14, 2017; Accepted: Sep 06, 2017 ; Published: Oct 03, 2017; Paper Id.: IJASROCT201749

\section{INTRODUCTION}

Farm women are the backbone of Indian agriculture. Growing food has been an interminable saga of her life. It is a well recognized fact that, more than $60 \%$ of agricultural operations have been traditionally handled by women. Even cultural anthropological literature suggests that, agriculture is invention of women. Rural woman is extensively involved in agricultural activities. The nature and extent of their involvement, differs with the variations in agro-production systems. The mode of female participation in agricultural production varies with the landowning status of farm household. Their roles range from managers to landless labourers (Vinod Kumar et al, 1985). Women are doing almost all the agricultural work, starting from the sowing of seeds to harvesting and processing the agricultural produce. Like other rural women, tribal farmwomen also play an important role in agriculture. No field operation is beyond the reach of women. Though, an overwhelming majority of tribal women (91\%) is involved in agriculture, half (44.3\%) of them were agricultural laborers. There are a large number of studies on tribal communities, but only few have focused on tribal women. Singh, 1993, restated that, there is material on tribal in general, but that, on tribal women specifically is limited. Keeping this fact in view, the investigation in Srikakulam district was undertaken, with objective of participation of tribal women in different farming activities. 


\section{Savara - Agricultural Scenario}

Savara is one of the agrarian tribes, situated in hamlets of Palakonda hills in Srikakulam district. Savaras are expert terrace cultivators. They prepare platforms, one over the other like steps in a stair case on the low gradient slopes and construct stone terraces, in order to catch and preserve the down flowering rain water from a hill stream. They raise paddy, ginger, turmeric, bananas, red gram, and grow vegetables and millets on hill and flat fields. During the lean season, they make ends meet on a variety of edible roots, tubers leaves and fruits collected from the forest.

\section{METHODOLOGY}

The study was undertaken in district Srikakulam, which was randomly selected out of all five districts of Andhra Pradesh, having tribal population. From Srikakulam, two blocks Palakonda (hilly) and Ganguwari Cigadam (plain) were selected randomly, and from the two blocks one village from each i.e., Rajam (plain) Palakonda (hilly) were selected randomly. 100 Savara tribal women, who were involved in farming, were selected randomly. Data was collected personally by the investigator, through the well structured interview schedule. Weighted mean score and ranks were used, to find out the participation of tribal women in different farming activities.

\section{RESULTS AND DISCUSSIONS}

Table 1: Participation of Tribal Women in the Farming

\begin{tabular}{|c|c|c|c|c|c|c|c|}
\hline S No & Farm Activities & $\begin{array}{l}\text { Self } \\
(\mathbf{F})^{*}\end{array}$ & $\begin{array}{l}\text { Joint } \\
(\mathrm{F})^{*}\end{array}$ & $\begin{array}{c}\text { Husband } \\
(\mathrm{F}) *\end{array}$ & $\begin{array}{c}\text { Children's } \\
\operatorname{Help}(\mathrm{F})^{*}\end{array}$ & $\begin{array}{c}\text { Weighted } \\
\text { Mean Score }\end{array}$ & Rank \\
\hline 1 & Ploughing & - & - & 50 & 13 & 1.13 & XXII \\
\hline 2 & Levelling & - & - & 49 & 14 & 1.12 & XXIV \\
\hline 2 & Ridging & 1 & 1 & 47 & 14 & 1.15 & XXI \\
\hline 3 & Loading and unloading cart & 1 & 19 & 31 & 12 & 1.35 & $\mathrm{XV}$ \\
\hline 4 & Mixing of Manure & 5 & 21 & 26 & 11 & 1.46 & $\mathrm{XI}$ \\
\hline 5 & Spreading Manure & 9 & 26 & 15 & 13 & 1.57 & VIII \\
\hline 6 & Manure Preparation & 34 & 10 & 6 & 13 & 1.91 & II \\
\hline 7 & Application & 2 & 19 & 23 & 19 & 1.31 & XVII \\
\hline 8 & Seed Treatment & 25 & 7 & 23 & 8 & 1.75 & IV \\
\hline 9 & Sowing & 4 & 10 & 38 & 11 & 1.33 & XVI \\
\hline 10 & Thinning & 2 & 11 & 36 & 14 & 1.27 & XVIII \\
\hline 11 & Gap Filling & 3 & 8 & 34 & 18 & 1.22 & $\mathrm{XX}$ \\
\hline 12 & Channel making & 2 & 5 & 36 & 20 & 1.15 & XXI \\
\hline 13 & Bunding of Fields & 2 & 9 & 36 & 16 & 1.23 & XIX \\
\hline 14 & Making of beds & 1 & 32 & 16 & 14 & 1.46 & $\mathrm{XI}$ \\
\hline 15 & Application of water & 4 & 42 & 4 & 13 & 1.63 & VII \\
\hline 16 & Chemical weeding & 1 & 20 & 30 & 12 & 1.36 & XIII \\
\hline 17 & Manual weeding & 12 & 31 & 15 & 5 & 1.76 & III \\
\hline 18 & Harvesting & 7 & 29 & 22 & 5 & 1.64 & VI \\
\hline 19 & Picking of earheads & 10 & 28 & 18 & 7 & 1.67 & $\mathrm{~V}$ \\
\hline 20 & Cleaning storage structure & 32 & 12 & 12 & 7 & 1.95 & $\mathrm{I}$ \\
\hline 21 & Transportation & 8 & 19 & 25 & 11 & 1.50 & IX \\
\hline 22 & Unloading of produce & - & 33 & 21 & 9 & 1.50 & IX \\
\hline 23 & Storing & - & 21 & 31 & 11 & 1.36 & XIII \\
\hline 24 & Transportation of produce & - & 7 & 46 & 13 & 1.17 & $\mathrm{XXV}$ \\
\hline 25 & Auction of produce & - & - & 49 & 14 & 1.12 & XXVI \\
\hline
\end{tabular}




\section{Frequency and Percentage are Same}

Above table reveals that, 63 percent of respondents were involved in farming. Maximum involvement of women was seen in activities of manure preparation, with a weighted mean score of 1.91, seed treatment (1.75), application of water (1.63), cleaning of stores (1.95), manual weeding (1.760), picking of ear heads (1.67) etc. These were done by self. Husband and children got involved in activities like ploughing (50\%), leveling (49\%), channel making (47\%), a band making, thinning as these are highly labor demanding works of farming. Joint work was done in few activities, such as application of water (42\%), making bonds (32\%), spreading manure (26\%) and loading and unloading the products (19\%). Once again, marketing work was done by husbands help only for the majority (49\%) of respondents. The overall weighted mean for this activity was found to be 1.42 , with $3^{\text {rd }}$ rank among all the activities.

The findings indicate that, majority of tribal women cultivators/farmers got their husband or children's help and assistance in hard activities like ploughing, leveling, ridging, bund making etc.

They involved themselves in some activities, such as watering, manure preparation and seed treatment contradicting the findings of Manju Sharma (2002), stating that, women's participation in post harvest operations was high compared to pre harvest operations. The activities in which, less technical experience is required like manual weeding, picking ear heads, cleaning, storage were done by the majority of respondents, showing their lack of technical skills in farming. The findings are in agreement with those of Saravanan and Rasmy (2001), stating that, women cultivators have inadequate access to modern agricultural technologies. Marketing activities, such as auction of produces, transport was usually done by husband for most $(49 \%)$ of the respondents.

Table 2: Relationship between Independent Variable of the Respondents and their Participation in Agricultural Activities

$\mathrm{N}=\mathbf{1 0 0}$

\begin{tabular}{|c|l|c|}
\hline S. No. & Independent Variables & Participation in Farming \\
\hline $\mathbf{1}$ & Education & $4.530^{*}$ \\
\hline $\mathbf{2}$ & Marital status & $3.594^{*}$ \\
\hline $\mathbf{3}$ & Occupation & $4.516^{*}$ \\
\hline
\end{tabular}

*Significant at $5 \%$ level.

Table 2 reveals that, education and occupation were significant at 5\% with the participation of tribal women in farming activities. It shows that, the independent variables are positively related to the participation of tribal women in farming.

\section{CONCLUSIONS}

Tribal women hold high and prestigious position in their tribal society, as they play a crucial role in contributing to the family's economy (Singh 1991).Tough majority (63\%) of the respondents were involved in farming /agriculture, as they remain as agricultural labours and only $10 \%$ were cultivators. The overall research showed that, in farm activities, participation of tribal women was found in activities like cleaning, storage structure with a weighted mean score (1.95) ranking first, followed by manure preparation (1.91) ranking second and seed treatment (1.75), among the farming activities. Less involvement of tribal women was studied in hard activities like ploughing transportation of produce, levelling of land ethic, as they require high energy and are strenuous. It is also shown that, the independent variables are positively related to the participation of tribal women in farming. 


\section{RECOMMENDATIONS}

- In admiration of the active involvement and participation of the tribal women in agriculture and farm activities, there is a need for reduction of their drudgery chiefly in weeding, harvesting and postharvest operations, to enable the tribal farm women to accomplish their activities, with no help from others.

- To enhance their productivity in terms of economy, they should be educated in effective and new technologies of farming systems like mixed framing system, integrated farming system etc. to increase their incomes.

\section{REFERENCES}

1. Kumar, Vinod, T.R. Singh, S.R. Yadav and R.P. Singh (1985), "Employment and Income Pattern of Women Labour in Modern Agriculture in District Meerut (U.P.)”, Indian Journal of Agricultural Economics, Vol. XL, No.3, July-September.

2. Sharma. M, (2002). Involvement of women in agricultural activities. Maharashtra J. Extn. Edu., 21(1) : 105-106.

3. Saravanan.R. and Rasmy,C. 2001.Strategies for empowering women cultivators. Agricultural Extension Review. 13 (1):3-7.

4. T. N. Sujeetha \& M. Anamica, Role Performance of Nilgiris Tribal Women in Animal Husbandry Operations, International Journal of Agricultural Science and Research (IJASR), Volume 7, Issue 2, March - April 2017, pp. 529-532.

5. Singh, K.S.1991.Status of Tribals in India. Primary census abstract for general population, scheduled castes and tribes.19711991.

6. Singh, A.K.1993 Tribes and tribal life approaches to development in tribal context. Sarup and Sons, New Delhi.: 34. 